\title{
PENILAIAN KELAYAKAN OBJEK PUPIL DARI FRAME CITRA MATA PADA APLIKASI PEMERIKSA MYOPIA MENGGUNAKAN STANDAR DEVIASI
}

\author{
Teady Matius Surya Mulyana ${ }^{1}$, Herlina $^{2}$ \\ ${ }^{1}$ Program Studi Teknik Informatika, Universitas Bunda Mulia Jakarta \\ Email:tmulyana@bundamulia.ac.id \\ ${ }^{2}$ Program Studi Teknik Informatika, Universitas Bunda Mulia Jakarta \\ Email: herlina@bundamulia.co.id
}

Masuk: 12-04-2019, revisi:04-11-2019, diterima untuk diterbitkan: 27-11-2019

\begin{abstract}
ABSTRAK
Proses penentuan visus pada penderita myopia berbasis computer vision memerlukan frame-frame citra yang berisi objek pupil yang dianggap memenuhi persyaratan sebelum masuk ke tahap penentuan visus. Persyaratan frameframe citra yang dianggap memenuhi persyaratan adalah frame-frame citra yang berisi objek dengan ukuran yang tidak terlalu kecil ataupun terlalu besar. Pengambalian frame-frame citra mata secara real-time mengakibatkan adanya frame citra mata yang ditangkap kamera ketika mata sedang berkedip, sehingga berisi objek pupil yang terlalu kecil. Proses penentuan nilai ambang pada binerisasi citra mata yang terlalu besar juga mengakibatkan objek pupil berbaur dengan bayangan di sekitar mata, sehingga menghasilkan objek yang terlalu besar. Sampel yang kecil pada pengambilan citra mata memerlukan perlakuan untuk penilaian statistik dengan sampel kecil. Jumlah sampel yang kecil dapat untuk menentukan kelayakan citra untuk masuk proses selanjutnya dapat diimplementasikan menggunakan standar deviasi. Nilai standar deviasi dapat mengakomodasi keperluan membatasi rentang ukuran objek pupil pada citra mata yang dianggap layak. Hasil akhir dari penelitian ini adalah implementasi metode penentuan suatu citra dianggap memiliki objek pupil dengan ukuran yang layak untuk diobservasi sehingga didapatkan interval yang sesuai kondisi masing-masing set citra mata yang direkam oleh kamera pada saat observasi mata. Penggunaan standar deviasi pada penentuan citra yang dianggap layak berkontribusi menaikkan persentase ketepatan penilaian visus mata pada aplikasi penentuan visus myopia secara real time dari $54 \%$ tanpa standar deviasi menjadi $73 \%$ pada nilai confidence untuk interval satu rata-rata sebesar $99 \%$ pada proses penentu visus myopia.
\end{abstract}

Kata kunci: computer vision; objek pupil; standar deviasi

\begin{abstract}
The process of determining vision in patients with myopia based on computer vision requires image frames containing pupil objects that are deemed to meet the requirements before entering the vision determination stage. Image frame requirements that are considered to meet the requirements are image frames that contain objects that are not too small or too large. The extraction of eye image frames in real-time results in eye image frames being captured by the camera when the eyes are blinking, so that they contain too small pupil objects. The process of determining the threshold value in binaryization of an eye image that is too large also results in pupillary objects blending with the shadows around the eye, resulting in objects that are too large. Small samples in eye image taking require treatment for statistical assessment with small samples. The small number of samples can be used to determine the feasibility of the image to enter the next process can be implemented using standard deviations. Standard deviation values can accommodate the need to limit the size range of pupil objects in the eye image that is considered feasible. The final result of this study is the implementation of the method of determining an image considered to have a pupil object of a size that is suitable for observation so that the interval is obtained according to the conditions of each set of eye images recorded by the camera during eye observation. The use of standard deviations in determining which images are considered feasible contributes to increasing the percentage of accuracy of eye vision assessment in the application of myopia vision determination in real time from 54\% without standard deviation to $73 \%$ in the confidence value for an average one-time interval of $99 \%$ in the process of determining myopia vision .
\end{abstract}

Keywords: computer vision; pupillary object; standard deviation 


\section{PENDAHULUAN}

Latar Belakang

Proses penentuan visus pada penderita myopia dengan menggunakan web kamera memerlukan frame-frame citra yang berisi objek yang dianggap memenuhi persyaratan sebelum masuk ke tahap penentuan visus. Persyaratan frame-frame citra yang dianggap memenuhi persyaratan adalah frame-frame citra yang berisi objek dengan ukuran yang tidak terlalu kecil.

Frame-frame citra perlu dipilih untuk memastikan setiap citra mata yang akan dinilai adalah frame citra mata yang berisi objek pupil dengan ukuran yang layak. Ketidak layakan ukuran objek pupil pada frame citra mata dapat disebabkan karena mata yang sedang berkedip pada saat pengambilan citra, sehingga ukuran pupil jauh lebih kecil daripada ukuran pupil pada peristiwa observasi pupil mata menggunakan web kamera. (Mulyana, 2016). Pada penelitian sebelumnya, nilai kelayakan citra adalah citra yang berisi pupil dengan luas berada pada interval rata-rata $+/-$ $25 \%$, dengan pertimbangan jika luas pupil kurang dari $25 \%$ dari rata-rata maka citra dianggap tidak berisi pupil dengan luas yang sesuai untuk diobservasi, dan luas pupil yang normal tidak mungkin lebih dari $25 \%$ nilai rata-rata. Karena berdasarkan asumsi, maka tidak ada pembuktian yang layak. Hasil yang didapatkan adalah banyak citra mata yang terpakai meskipun tidak termasuk layak untuk diobservasi, sehingga mengakibatkan kurang akuratnya penentuan visus. Keakuratan pengukuran visus dengan menggunakan interval tersebut hanya $56 \%$ dengan menggunakan nilai confidence untuk interval rata-rata sebesar $99 \%$.

Citra-citra yang diambil akan berisi objek-objek pupil dengan variasi ukuran yang berbeda. Variasi ukuran yang diharapkan adalah variasi yang terjadi karena reaksi pupil ketika berusaha melihat objek huruf snellen yang ditampilkan. Sedangkan ukuran pupil yang tidak diharapkan adalah ukuran pupil yang didapat karena sebagian atau seluruh pupil tertutup kelopak mata ketika mata sedang berkedip. (Mulyana, 2018)

Alwi (Alwi, 2012) menjelaskan bahwa penentuan sampel merupakan langkah yang sangat penting dalam perencanaan studi statistik dan analisis item. Karenanya penentuan sampel perlu direncanakan sebaik mungkin. Standar deviasi merupakan salah satu pilihan untuk melakukan penilaian untuk menentukan citra dianggap layak atau tidak layak untuk masuk proses selanjutnya. Dengan sampel yang kecil diperlukan pula perlakuan untuk penilaian statistik dengna sampel kecil. Dan diperlukan pula suatu nilai standar deviasi yang dapat mengakomodasi keperluan membatasi rentang ukuran objek pupil pada citra mata yang dianggap layak. 

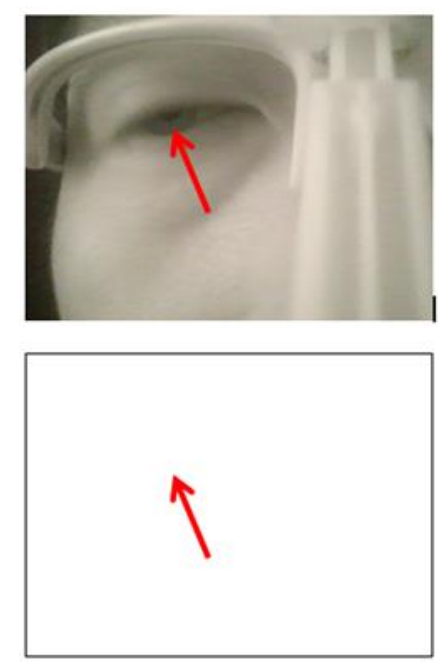

(a)
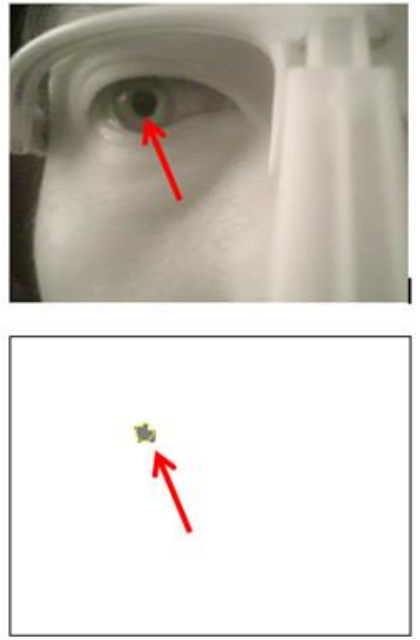

(b)

Gambar 1. Hasil Segmentasi Objek Pupil Dari Citra Mata

Sumber:...

Gambar 1.a. Memperagakan bagaimana seharusnya citra dengan pupil yang terlalu kecil akibat mata sedang berkedip seharusnya tidak menghasilkan objek pupil pada proses segmentasinya. Sedangkan Gambar 1.b. memperagakan objek pupil yang pada mata yang terbuka lebar dapat disegmentasi posisi maupun luas yang seharusnya.

Lenth, (Lenth, 2001), Santi (Santi, 2015), Yusnianti (Yusnianti, 2016) dan Budiaji (Budiaji, 2012) menjelaskan Statistika deskriptif adalah metode-metode yang berkaitan dengan pengumpulan dan penyajian suatu gugus data sehingga memberikan informasi yang berguna. Dalam statistika, untuk membuat sebuah data yang akurat dan dapat dipercaya dapat dilakukan sebuah observasi (pengamatan) secara langsung dan bertahap. Abidin (Abidin, 2015) menjelaskan secara umum rumus standart deviasi dihadirkan seperti pada rumus (1)

$$
S=\sqrt{\frac{\sum_{i=1}^{n}\left(x_{i}-\bar{x}\right)}{n-1}}
$$

Dengan $\mathrm{S}=$ Standart Deviasi, $\mathrm{n}=$ jumlah sampel, $\mathrm{x}_{\mathrm{i}}=$ data ke $\mathrm{i}$, dan $\bar{x}=$ rata-rata

Lind (Lind, 2012), Black (Black, 2013), Marlita (Marlita, 2014) dan Hanifah (Hanifah, 2016) menjelaskan standar deviasi secara umum digunakan sebagai ukuran untuk membandingkan persebaran dua atau lebih dari kelompok pengamatan. Standar deviasi yang kecil pada suatu kelompok nilai menunjukan bahwa nilai-nilai tersebut terletak di dekat rata-rata. Sebaliknya 
standar deviasi yang besar menyatakan bahwa pengamatan terpencar dengan luas dari rataratanya. Ahli matematika Rusia P.L Chebyshev (1821-1894) mengembangkan teorema yang memungkinkan untuk menentukan proporsi minimum dari nilai-nilai yang terletak pada angka standar deviasi tertentu dari rata-ratanya. Karena objek pupil yang digunakan harus berada pada luasan objek pupil dari citra yang terletak didekat rata-rata, maka standar deviasi dapat dipergunakan untuk menentukan interval citra dianggap layak. Maddeppungeng (Maddeppungeng, 2018) dan Kristiantoro (Kristiantoro, 2016) menggunakan pesebaran nilai yang dekat dengan nilai rata-rata. Pesebaran ini dapat digunakan untuk mengukur ketidakpastian secara teknis pada pesebaran hasil pengukuran di dekat nilai rata-rata dari hasil pengukuran.

\section{Rumusan Masalah}

Rumusan masalah dari penelitian ini adalah bagaimana penerapan standar deviasi terhadap luas masing-masing objek pupil pada pemilihan citra mampu memilih citra yang dianggap layak. Selain itu dirumuskan pula bagaimana pengaruh nilai luas pupil yang terkandung pada citra yang terlalu besar akibat objek pupil berbaur dengan bayangan disekitar mata berpengaruh pada nilai standar deviasi.

\section{Urgensi Penelitian}

Penelitian ini diperlukan untuk penentuan kelayakan awal objek bergerak yang terkandung pada citra berdasarkan ukurannya, sehingga dapat ditentukan kelayakan suatu objek untuk di analisis. Penelitian ini pada awalnya ditujukan untuk melengkapi proses penilaian myopia berbasis computer vision, tetapi metode yang sama dapat dilakukan pada citra dengan objek yang dapat berubah ukurannya setiap saat untuk menilai kelayakan suatu citra untuk dianalisa.

\section{METODE PENELITIAN}

Program pemeriksa visus dirancang dengan menampilkan huruf-huruf dari tiap ukuran mulai dari yang besar sampai yang terkecil sesuai dengan ukuran pada snellen chart. Flowchart dari program dapat dilihat pada gambar 2. Ketika tiap-tiap huruf ditampilkan citra mata ditangkap dengan kamera web. Semua citra mata tersebut disimpan pada memori untuk diukur objek pupilnya sehingga dapat digali informasi ketika objek pupil dari setiap himpunan citra yang mewakili nilai baris snellen sedang mengecil yang menandai baris pada snellen tersebut tidak dapat dibaca oleh pasien.

Penentuan visus dari pasien dilakukan dengan terlebih dahulu mencari nilai luas objek pupil dari sampel terpilih. Sampel awal dipilih secara manual dari 20 citra pertama, di mana citra tersebut 
merupakan citra ketika huruf terbesar ditampilkan. Nilai luas pupil diambil untuk menentukan valid tidaknya setiap objek pupil dari semua citra mata tersimpan.

Berdasarkan rumus (1), maka proses penentuan interval dilakukan dengan menjumlahkan semua luas objek pupil yang didapatkan dari proses segmentasi pupil, kemudian dibagi dengan jumlah data untuk mendapatkan nilai rata-rata dari semua sampel. Berdasarkan nilai rata-rata yang didapat tersebut, dicari perbedaan semua jarak luas objek pupil dan dijumlahkan. Hasil dari penjumlahan perbedaan nilai pupil dengan nilai rata-rata tersebut dibagi dengan jumlah sampel dikurangi 1. Langkah terakhir adalah dengan mencari akar dari nilai tersebut untuk mendapatkan nilai standar deviasi.

Dengan menggunakan nilai standar deviasi tersebut, citra mata yang akan diobservasi akan dibandingkan. Jika luas objek pupil berada pada interval yang sesuai dengan nilai rata-rata sampel +/- nilai standar deviasi, maka citra dapat dipergunakan untuk observasi menggunakan interval satu rata-rata yang sudah dirancang pada penelitian sebelumnya.

\section{Implementasi Pada Program}

Penggunaan standar deviasi untuk menentukan interval citra yang dianggap layak diterapkan pada program yang diepragakan pada gambar 3. Baris 2856 sampai baris 2872 merupakan penentuan nilai rata-rata dari semua sampel citra. Baris 2867 menentukan nilai yang dijumlahkan untuk mengisi kekosongan data berdasarkan nilai ambang suspect yang didapat dari luas salah satu citra pupil jika citra tidak berisi objek pupil sama sekali. 

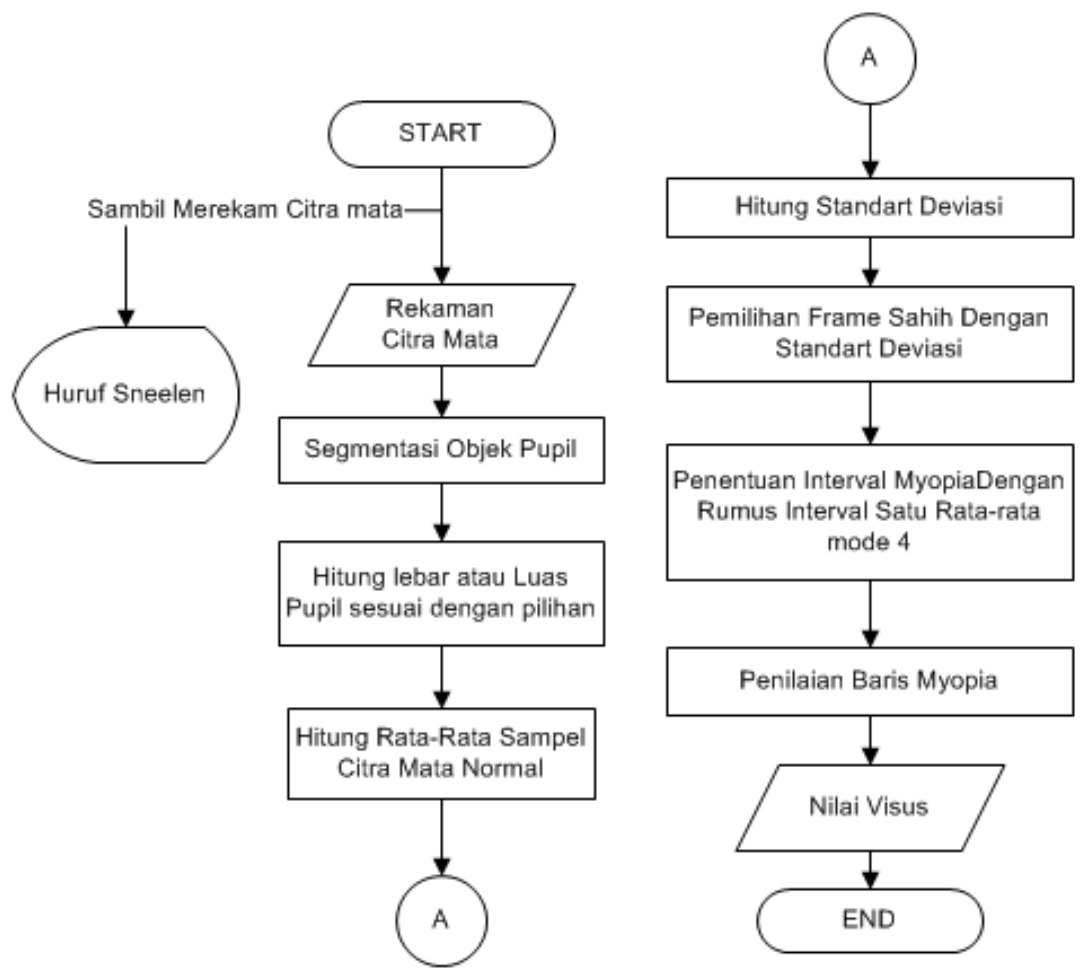

Gambar 2. Proses Utama Penentuan Visus

Sumber: ...

Baris 2873 sampai baris 2881 merupakan penentuan nilai akhir dari standar deviasi, dimana setiap nilai luas pupil dikurangi dengan nilai rata-ratanya sebelum dijumlahkan, kemudian hasil penjumlahan semua jarak nilai luas pupil dengan nilai rata-rata dibagi dengan jumlah sampel yang sebelumnya dikurangi 1 sesuai dengan rumus standar deviasi yang dipergunakan, kemudian terakhir dicari nilai akarnya sehingga menghasilkan nilai Standar deviasi. Dapat dilihat pada baris 2881 .

Nilai interval citra yang dianggap layak adalah nilai rata-rata dikurangi nilai standar deviasi sampai nilai rata-rata ditambah nilai standar deviasi. Sehingga pada program nantinya akan dipilih citra yang akan diobeservasi apakah memiliki objek pupil dengan luas yang sesuai dengan nilai interval citra layak tersebut.

Salah satu masalah pada penggunaan standar deviasi adalah jika ada beberapa nilai yang terlalu besar ataupun terlalu kecil, maka nilai standar deviasi akan terlalu besar. Karena itu pada program diterapkan pula pembatasan dengan area elips agar pupil yang tidak fokus pada objek huruf snellen tidak diproses, melainkan diberi nilai sesuai dengan nilai ambang dengan demikian luas objek pupil yang terlalu besar atau terlalu kecil tidak dipergunakan pada penentuan standar deviasi. Penentuan nilai terbesar adalah citra yang berisi pupil dengan luas berada pada interval rata-rata $+/-25 \%$ dari nilai ambang yang dipilih, dengan pertimbangan jika luas pupil kurang dari $25 \%$ dari rata-rata maka citra dianggap tidak berisi pupil dengan luas yang sesuai untuk 
diobservasi, dan luas pupil yang normal tidak mungkin lebih dari $25 \%$ nilai rata-rata. Atau dengan kata lain nilai standar deviasi dibatasi maksimum $+/-25 \%$.

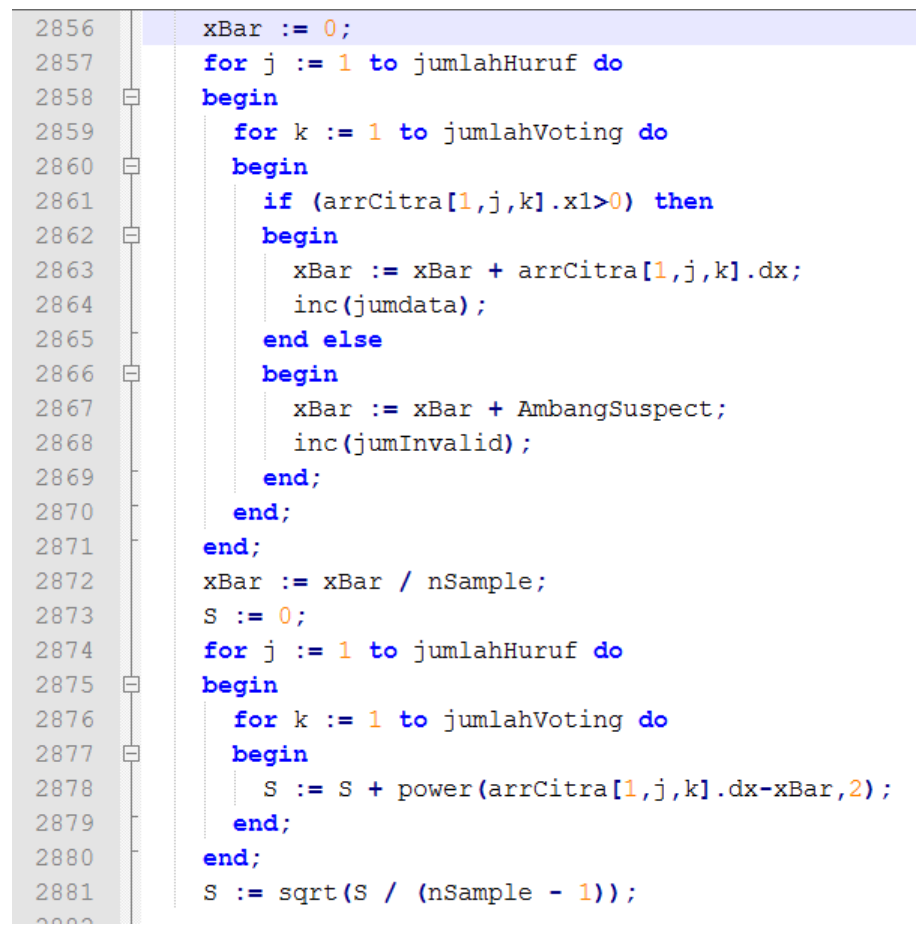

Gambar 3. Kode Program Penentuan Standar Deviasi

Sumber: ...

\section{HASIL DAN PEMBAHASAN}

Sesuai dengan penelitian terdahulu, (Mulyana, 2018), analisis keberhasilan metode dilakukan dengan membandingkan keberhasilan pengukuran secara manual. Hasil analisis nantinya berupa persentase keberhasilan metode. Keberhasilan yang dimaksud adalah kesesuaian visus tidak terbaca pada pengukuran secara manual dengan penentuan visus yang dihasilkan oleh program.

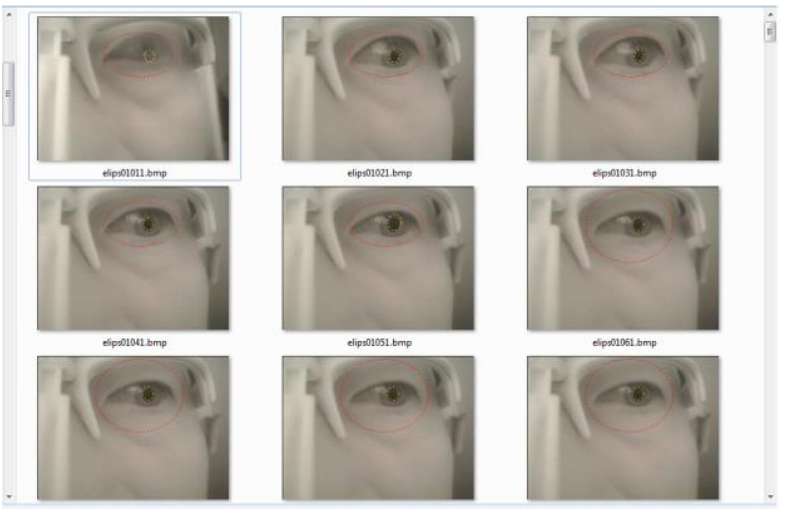

(a). Citra Asal

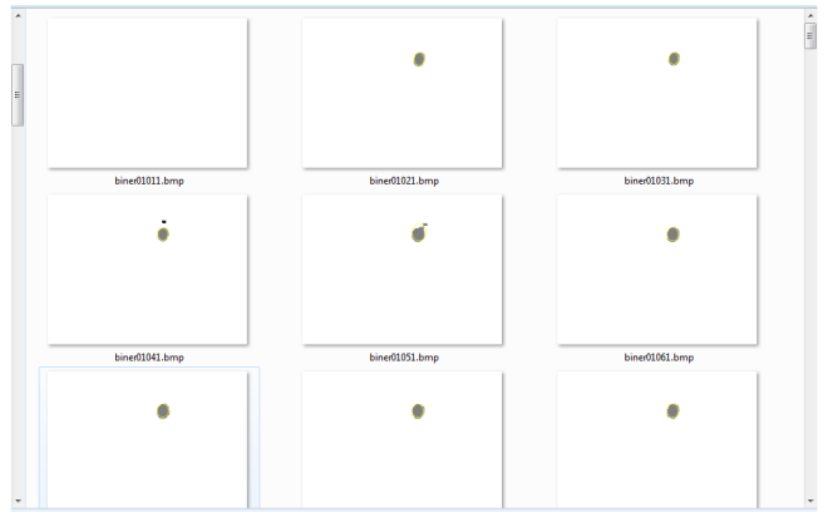

(b). Pupil Hasil Segmentasi

Gambar 4. Contoh Data Sampel 
Sumber: ...

Contoh data sampel pengujian dapat dilihat pada Gambar 4. Kumpulan Citra yang digunakan ujicoba berupa satu set citra mata yang ditangkap dengan kamera inframerah, contoh dapat dilihat pada gambar 4.(a). sedangkan citra hasil segmentasi pupil yang akan dihitung pada perhitungan dengan standar deviasi dapat dilihat pada Gambar 4.(b). Setiap set sampel citra terdiri dari 11 baris test visus dikalikan dengan masing-masing 30 citra per visus, sehingga total tiap set sampel citra adalah 330 citra. Pengujian dilakukan terhadap 30 set sampel. Yang disimpan tiap set perfolder.

Karena pembanding adalah pengukuran secara manual, maka keberhasilan diberi toleransi satu baris di atas atau di bawah hasil pengukuran secara manual. Dengan alasan pada pengukuran secara manual seringkali bisa jadi mata yang di observasi akan melakukan akomodasi agar dapat membaca huruf yang ditampilkan. Sedangkan pada aplikasi penilaian visus dilakukan ketika mata mulai berakomodasi atau pupil mengecil.

Tabel 1. Contoh Hasil Pengujian

\begin{tabular}{lcccc}
\hline & $\begin{array}{c}\text { Percobaan } \\
\mathbf{1}\end{array}$ & Percobaan 2 & $\begin{array}{c}\text { Percobaan } \\
\mathbf{3}\end{array}$ & Percobaan 4 \\
\hline Rata-Rata Luas Pupil & 333.9 & 329.733 & 326,567 & 327.067 \\
\hline Jarak Terbesar dengan mean & 159.1 & 163.267 & 226.567 & 165.933 \\
\hline Standar Deviasi & $17.001 \%$ & $17.983 \%$ & $20.992 \%$ & $18.249 \%$ \\
\hline $\begin{array}{l}\text { Keberhasilan Pengukuran } \\
\text { Visus }\end{array}$ & $81 \%$ & $70 \%$ & $76 \%$ & $80 \%$ \\
\hline
\end{tabular}

Tabel 1 menampilkan sebagian hasil percobaan pengukuran visus yang sudah mempergunakan standar deviasi pada penentuan kelayakan objek. Secara keseluruhan keberhasilan pengukuran visus adalah $73 \%$ pada nilai confidence untuk interval satu rata-rata sebesar 99\%. Dengan mengkondisikan nilai luas objek pupil yang berbeda jauh dari nilai ambang yang dipilih menggunakan nilai ambang tersebut, nilai standar deviasi yang dihasilkan adalah $16 \%$ sampai 22\%. Dengan perbedaan jarak terbesar dengan nilai rata-rata (mean) adalah 150 sampai 170. Rata-rata luas pupil ditampilkan hanya sebagai informasi nilai rata-rata sebenarnya yang menghasilkan standar deviasi tersebut. Pada penelitian ini tidak diteliti hubungan nilai rata-rata dengan nilai standar deviasi yang dihasilkan.

Tabel 2. Contoh Hasil Pengujian Tanpa Pembatasan Luas Objek Pupil

\section{Percobaan Percobaan 2 Percobaan Percobaan 4}




\begin{tabular}{lcccc}
\hline \multicolumn{4}{c}{$\boldsymbol{1}$} & \multicolumn{3}{c}{$\mathbf{3}$} \\
\hline Rata-Rata Luas Pupil & 354.267 & 434.233 & 301.1 & 399.967 \\
\hline Jarak Terbesar dengan mean & 681.733 & $1,565.77$ & 226.567 & $1,600.03$ \\
\hline Standar Deviasi & $39.983 \%$ & $90.840 \%$ & $37.906 \%$ & $83.24 \%$ \\
\hline $\begin{array}{l}\text { Keberhasilan Pengukuran } \\
\text { Visus }\end{array}$ & $63 \%$ & $43 \%$ & $62 \%$ & $40 \%$ \\
\hline
\end{tabular}

Sebagai pembanding dilakukan pula percobaan dengan menggunakan proses tanpa pembatasan nilai luas objek piksel. Sehingga didapatkan nilai luas objek pupil yang terlalu besar dan terlalu kecil untuk mendapatkan nilai standar deviasi. Nilai standar deviasi yang dihasilkan sangat besar, dan keberhasilan pengujian sangat rendah. Kebanyakan pengujian menghasilkan nilai visus yang mendekati normal, berbeda dengan pengukuran secara manual yang digunakan sebagai pembanding.

\section{KESIMPULAN DAN SARAN}

\section{Kesimpulan}

- Penggunaan standar deviasi untuk menentukan kelayakan suatu citra berisi objek pupil yang layak untuk diobservasi dapat meningkatkan keakuratan aplikasi penentuan visus myopia.

- Secara keseluruhan keberhasilan pengukuran visus adalah $73 \%$ pada nilai confidence untuk interval satu rata-rata sebesar $99 \%$.

- Nilai objek pupil yang berbeda terlalu besar dibandingkan mayoritas nilai mayoritas objek pupil sangat mempengaruhi nilai standar deviasi yang dihasilkan.

- Penggunaan nilai standar deviasi dapat menghasilkan interval yang tidak terlalu jauh dari nilai rata-rata dengan mengkondisikan nilai luas objek pupil yang berbeda jauh dari nilai ambang yang dipilih menggunakan nilai ambang tersebut, dengan nilai standar deviasi yang dihasilkan adalah $16 \%$ sampai $22 \%$.

\section{Saran}

Penggunaan standar deviasi sebagai penentu suatu objek yang terdapat pada citra dapat dipergunakan secara luas termasuk pada OCR maupun proses computer vision lainnya yang memerlukan penentuan kelayakan objek hasil segmentasi citra untuk diproses lebih lanjut.

\section{REFERENSI}

Abidin., Z., Purbawanto, S., (2015), Pemahaman Siswa Terhadap Pemanfaatan Media Pembelajaran Berbasis Livewire Pada Mata Pelajaran Teknik Listrik Kelas X Jurusan Audio Video Di Smk Negeri 4 Semarang, Edu Eletrika Jurnal Vol 4 Nomor 1, 2015, pISSN: 2252-7092

Black, Ken. (2013). Applied Business Statistics. 7th Edition. John Wiley \& Sons, Inc. 
Budiaji. Weksi, Suherna, Salampessy. Yudi L. A., (2012). Pedugaan Standar Deviasi Untuk Sampel Kecil Dalam Penelitian Pertanian, Jurnal Ilmu Pertanian dan Perikanan Desember 2012 Vol. 1 No.1 p : 37-42 (ISSN 2302-6308)

Hanifah, N., (2016), Perbedaab Hasil Belajar Materi Elastisitas Melalui Model Pembelajaran Kooperatif Tipe Jigsaw Dan Student Archievment Division Siswa Kelas X SMA Negeri 15 Banda Aceh, Jurnal Ilmiah Mahasiswa (JIM) Pendidikan Fisika. Vol. 1 No.3 Juli 2016, 6773

Idrus, Alwi, (2012), Kriteria Empirik dalam Menentukan Ukuran Sampel Pada Pengujian Hipotesis Statistika dan Analisis Butir, FORMATIF Jurnal Ilmiah Pendidikan MIPA, Vol 2, No 2 (2012)(DOI: http://dx.doi.org/10.30998/formatif.v2i2.95)

Kristiantoro. T., Idayanti. N., Sudrajat. N., Septiani. A., Mulyadi. D., Dedi, (2016), Ketidakpastian Pengukuran pada Karakteristik Material Magnet Permanen dengan Alat Ukur Permagraph, JURNAL ELEKTRONIKA DAN TELEKOMUNIKASI, Vol. 16, No. 1, Juni 2016

Lenth., Russell V., (2001) Some Practical Guidelines for Effective Sample Size Determination, The American Statistician, Vol. 55, No. 3. (Aug., 2001), pp. 187-193.

Lind, Douglas A. et al. (2012). Statistical Techniques in Business and Economics. McGraw Hill.

Mantel, N, 1951, Rapid Estimation of Standard Errors of Means for Small Samples. The American Statistician, vol. 5, No. 4 (Oct, 1951), pp. 26-27.

Maddeppungeng., A., Rifky Ujianto. R., Fella. M., (2018), Penerapan Metode Simulasi Monte Carlo Terhadap Risiko Finansial Proyek Rekontruksi, Jurnal Fondasi, Volume 7 No 2 2018, hal 1-10 (DOI: http://dx.doi.org/10.36055/jft.v7i2.4070)

Marlita. D., (2014), Pengaruh Pengawasan dan Budaya Kerja Terhadap Kinerja Pegawai Di Kantor KEcamatan Bontang Selatan, eJournal Ilmu Pemerintahan, 2 (4), 2014 : p:32463258

Mulyana. Teady.M.S., Hartono. Henny., (2016), Aplikasi Pemeriksa Mata Minus, Universitas Bunda Mulia, Jakarta, PDP scheme of DIKTI Research Grant Report, not published

Mulyana. Teady.M.S., Herlina, (2018), Deteksi Pupil Sedang Berakomodasi Berbasis Computer Vision Menggunakan Metode Interval Satu Rata-Rata, Prosiding SEMNASTEK 2018 Fakultas Teknik, Universitas Muhammadiyah Jakarta, 17 Oktober 2018, p-TINF18

Santi. Rina C.N., Eniyati. Sri, (2015), Implementasi Statistik dengan Database Mysql, Jurnal Teknologi Informasi DINAMIK Volume 20, No.2, Juli 2015 p: 132-139 (ISSN : 08549524)

Yusniyanti., E., Kurniati (2017), Analisa Puncak Banjir Dengan Metode MAF (Studi Kasus Sungai Krueng Keureuto), JURNAL EINSTEIN Jurnal Hasil Penelitian Bidang Fisika, Vol 5, No 1 (2017) 